\title{
MODEL DEVELOPMENT OF ADDITIVES DISSOLUTION IN THE BOF PROCESS*
}

\author{
Daniel Augusto Godinho de Carvalho ${ }^{1}$ \\ Johannes Schenk ${ }^{2}$ \\ José Adilson Castro ${ }^{3}$
}

\begin{abstract}
Since the beginning of BOF process, slag formation has been subjected to extensive development. During the initial stages of the blow, fast slag formation is primordial for the process performance. This is mainly to allow oxidizing reactions, and also to protect the refractory. A modeling of BOF process for the purpose of process optimization requires precise knowledge concerning the dissolution of $\mathrm{CaO}$ and $\mathrm{MgO}$ based materials. Using this knowledge, the optimal process conditions can be ensured by a controlling of the slag formation during the converter steelmaking process. Taking into account an application of large amount of different raw materials, as well as location-specific process conditions, the characterization of the dissolution behavior of different additives is an important key to improve the technological process. Thereby, in the frames of this project, an appropriate model for slag formation is established and compared to operational results for a 330t BOF, operating at ThyssenKrupp CSA, Santa Cruz, Brazil.

Keywords: BOF; Slag; Flux; Dissolution; Modeling.
\end{abstract}

Metallurgical Engineer, Steel Plant, ThyssenKrupp CSA, Rio de Janeiro, Brazil.

Univ.-Prof. Dipl.-Ing. Dr. techn, Montanuniversität Leoben, Styria, Austria.

Prof. P.hD, Universidade Federal Fluminense - UFF, Volta Redonda, Rio de Janeiro, Brazil. 


\section{INTRODUCTION}

BOF slag is created by fluxing the first " $\mathrm{FeO}$ "- $\mathrm{SiO}_{2}$ rich slag with the addition of slag formers as a burnt lime with high contents of $\mathrm{CaO}$ and dolomitic lime as $\mathrm{MgO}$ source. A good rate of slag formation during the blow, with high contents of $\mathrm{CaO}$ and $\mathrm{MgO}$ close to saturation is crucial for the process performance and can be governed by the degree of dissolution, a key for understanding the progress of slag-metal reactions in the steelmaking system.

\section{MATERIAL AND METHODS}

According to experiments conducted by Matsushima [1] the dissolution rate of fluxes, $v_{r}(\mathrm{~m} / \mathrm{min})$, into slag systems are controlled by mass transfer, and can be defined, assuming spherical geometry, as the dissolved volume per unit area in a unit of time.

$$
v_{r}=-\frac{1}{S} \frac{d V}{d t}=-\frac{d r}{d t}
$$

In a recent research, proposed by Dogan [2], the number of particles $\left(n_{i}\right)$ dissolved in the slag is proportional to the particle concentration, individual calculation for different particle size is calculated, and the results are then; the sum of all particles (Equation 2). The amount of flux dissolved (Equation 3) in emulsion at time t, $M_{d, f l u x}^{t}$ is determined by summation of total amount of lime dissolved at time $t-\Delta t$ and amount of lime dissolved at given time step $\Delta$ t. Subscript $d$ refers to dissolved flux in emulsion.

$$
\begin{aligned}
\frac{d W_{i}}{d t} & =-\rho_{i} S \frac{d r}{d t} n_{i} \\
M_{d, \text { flux }}^{t} & =M_{d, f l u x}^{t-\Delta t}+\frac{d W_{L}}{d t} \Delta t
\end{aligned}
$$

\subsection{Lime Dissolution Mechanism}

For stagnant laboratory experiments, irrespective of the lime type, the dissolution mechanism is very fast in the " $\mathrm{FeO}$ "- $\mathrm{SiO}_{2}$ slags, while the reaction became extremely slow in the case of $\mathrm{CaO}$ - $\mathrm{FeO}$ "- $\mathrm{SiO}_{2}$ slags due a di-calcium silicate formation, the main dissolution mechanism of lime is assumed to be controlled by $\mathrm{CaO}$ diffusion through a boundary layer according to Matsushima [1].

$$
-\frac{d r}{d t}=k \frac{\rho_{\text {slag }}}{100 \rho_{\text {Lime }}}\left(\% \mathrm{CaO}_{\text {saturation }}-\% \mathrm{CaO}_{\text {slag }}\right)
$$

\subsubsection{CaO saturation}

The saturation of $\mathrm{CaO}$ can be calculated according to Schürmann's [3] research, where the $\mathrm{CaO}$ saturation is calculated by the conversion of all oxides contents in a in a simple quasi ternary system $\mathrm{CaO}^{*}-\mathrm{FeO}_{\mathrm{t}}{ }^{*}-\mathrm{SiO}_{2}{ }^{*}$. $\mathrm{MnO}$ should not be considered into accounts, because has only a diluting (Equation 5) effect and all the other elements should be recalculated without $\mathrm{MnO}$ (Equation 6).

$$
\begin{aligned}
F_{M n O} & =\frac{100}{100-\% M n O} \\
\%(\text { Oxide })^{\prime} & =F e_{M n O} . \% \text { Oxide }_{\text {Initial }}
\end{aligned}
$$

The analytical concentration of each component in the steelmaking slags are normalized by considering the equivalent amount designated in terms of mass; 


$$
\% \mathrm{FeO} *=\mathrm{FeO}
$$

$\mathrm{CaO}$ saturation for reference temperatures $\left(1600^{\circ} \mathrm{C}\right)$, in the quasi-ternary slag system system, $\mathrm{CaO}^{*}-\mathrm{FeO}_{\mathrm{t}}{ }^{*}-\mathrm{SiO}_{2}{ }^{*}$, can be calculated according to mathematical description presented below, where $\varphi=\% \mathrm{FeO}_{n} * / \% \mathrm{SiO}_{2} *$.

$$
\% \mathrm{CaO}_{s}^{*}=100-(1+\varphi) \cdot\left[-\frac{\left(\frac{(-0.64 . \varphi-1)}{\left(0.00212 \varphi^{2}\right)}\right)}{2}-\sqrt{\left(\frac{\left.\left(\frac{(-0.64 . \varphi-1)}{\left(0.00212 \varphi^{2}\right)}\right)\right)^{2}}{2}-\left(\frac{32}{\left(0.00212 \varphi^{2}\right)}\right)\right]}\right.
$$

In order to consider the influence of temperature on lime saturation, allowing a complete mathematical description of the lime saturation contents in the system $\mathrm{CaO}^{*}-\mathrm{FeO}_{\mathrm{t}}{ }^{*}-\mathrm{SiO}_{2}{ }^{*}$ dependent on slag composition and temperature.

$$
\% \mathrm{CaO}_{\text {Sat } T\left({ }^{\circ} \mathrm{C}\right)}^{*}=\% \mathrm{CaO} \mathrm{O}_{S}^{*}+0.0225 .\left(T_{\text {Slag }}-1600\right)
$$

\subsection{Dolomitic Lime Dissolution Mechanism}

Dolomitic lime has a tendency to form a solid product with FeO. Umakoshi [4], suggested that diffusion of dolomitic lime is controlled by $\mathrm{CaO}$ dissolution of $\mathrm{CaO}$ through a boundary layer when the $\mathrm{FeO}$ content in slag is lower than $20 \%$ (Equation 12), otherwise $\mathrm{MgO}$ is the rate limiting for $\mathrm{FeO}$ concentrations higher than $20 \%$ (Equation 13).

$$
\begin{aligned}
& -\frac{d r}{d t}=\left(1+\frac{M_{M g O}}{M_{\text {CaO }}}\right) \cdot k_{\text {dol }} \cdot \frac{\rho_{\text {slag }}}{100 \rho_{\text {dolime }}} \cdot\left(\% \mathrm{CaO}_{\text {saturation }}-\% C a O_{\text {slag }}\right) \\
& -\frac{d r}{d t}=\left(1+\frac{M_{\text {CaO }}}{M_{M g O}}\right) \cdot k_{d o l} \cdot \frac{\rho_{\text {slag }}}{100 \rho_{\text {dolime }}}\left(\% M_{\text {glion }} O_{\text {saturation }}-\% M g O_{\text {slag }}\right)
\end{aligned}
$$

\subsubsection{MgO saturation}

In the present study, the $\mathrm{MgO}$ saturation levels is calculated according to a mathematical description of magnesia saturation in complex steelmaking slags proposed by Schürmann [5], all steps are similar to the $\mathrm{CaO}$ saturation proposed in this study.

$$
\begin{gathered}
\% \mathrm{CaO}^{*}=\% \mathrm{CaO}+0.59 . \% \mathrm{MnO}+0.37 . \% \mathrm{P}_{2} \mathrm{O}_{5}+0.21 . \% \mathrm{Al}_{2} \mathrm{O}_{3} \\
\% \mathrm{SiO}_{2}{ }^{*}=\% \mathrm{SiO}_{2}+ \\
0.63 . \% \mathrm{P}_{2} \mathrm{O}_{5}+0.79 . \% \mathrm{Al}_{2} \mathrm{O}_{3}+0.41 . \% \mathrm{MnO} \\
\% \mathrm{FeO}_{t}^{*}=\mathrm{FeO}_{t}
\end{gathered}
$$

Then, the normalized values for $\mathrm{CaO}-\mathrm{FeO}_{\mathrm{t}}-\mathrm{SiO}_{2}$ are.

$$
\begin{gathered}
\% \mathrm{CaO}^{\Delta}=100 . \% \mathrm{CaO}^{*} /\left(\% \mathrm{CaO}^{*}+\% \mathrm{SiO}_{2}{ }^{*}+\% \mathrm{Fe}_{t} \mathrm{O}^{*}\right) \\
\% \mathrm{SiO}_{2}{ }^{\Delta}=100 . \% \mathrm{SiO}_{2}{ }^{*} /\left(\% \mathrm{CaO}^{*}+\% \mathrm{SiO}_{2}{ }^{*}+\% \mathrm{Fe}_{t} \mathrm{O}^{*}\right)
\end{gathered}
$$




$$
\% \mathrm{FeO}_{t}{ }^{\Delta}=100-\% \mathrm{SiO}_{2}{ }^{\Delta}-\% \mathrm{CaO}^{\Delta}
$$

The mathematical descriptions presented below describe the $\mathrm{MgO}$ saturation;

$$
\% \mathrm{MgO}_{s, 1600}=a+b \cdot \% \mathrm{SiO}_{2}{ }^{\Delta}+0.01354 \cdot\left(\% \mathrm{SiO}_{2}{ }^{\Delta}\right)^{2}
$$

The factors (a) and (b) are function of normalized total iron oxide, and are described below.

$$
\begin{gathered}
a=7.989-0.1547 . \% \mathrm{FeO}_{t}{ }^{\Delta}+0.001232 .\left(\% \mathrm{FeO}_{t}{ }^{\Delta}\right)^{2} \\
b=-0.4374+0.01034 . \% \mathrm{FeO}_{t}{ }^{\Delta}
\end{gathered}
$$

A complete mathematical description of the $\mathrm{MgO}$ saturation contents in the system $\mathrm{CaO} *-\mathrm{FeO}_{\mathrm{t}}{ }^{*}-\mathrm{SiO}_{2}{ }^{*}$ dependent on slag composition and temperature is described below.

$$
\% M g O_{s a t, T(K)}=\left(\% M g O_{s, 1600}\right) \cdot e^{\left(5.5478-\frac{10391}{T(K)}\right)}
$$

\subsection{Slag Properties}

\subsubsection{Density of multicomponent slags}

An additive method for the estimation of densities in alloys and slags has been widely used. In this method, proposed by Keene [6] the density can be obtained from the following equation.

$$
\rho=\frac{M_{1} x_{1}+M_{2} x_{2}+M_{3} x_{3}+\cdots}{x_{1} V_{1}^{\prime}+x_{2} V_{2}^{\prime}+x_{3} V_{3}^{\prime}+\cdots}
$$

Where, $\rho=$ Density $\left(\mathrm{g} / \mathrm{cm}^{3}\right), M=$ Molecular weight $(\mathrm{g} / \mathrm{mol}), x=$ Mole fraction, $V^{\prime}=$ Partial molar volume $\left(\mathrm{cm}^{3} / \mathrm{mol}\right)$.

Table 1. Recommended values for partial molar volume of slag constituents (Slag Atlas, 1995)

\begin{tabular}{|c|c|}
\hline Constituent & $\mathrm{V}\left(\mathrm{cm}^{3} / \mathrm{mol}\right)$ \\
\hline $\mathrm{CaO}$ & 20.7 \\
\hline $\mathrm{MgO}$ & 16.1 \\
\hline $\mathrm{MnO}$ & 15.6 \\
\hline $\mathrm{FeO}$ & 15.8 \\
\hline $\mathrm{SiO}_{2}$ & $19.55+7.996 x_{\mathrm{SOO} 2}$ \\
\hline
\end{tabular}

\subsubsection{Viscosity of multicomponent slags}

In order to calculate the viscosity of slags, a model proposed by Mills [7] is applied, the slags constituents are divided in three categories; glass formers (Equation 25) modifiers (Equation 26) and amphoterics (Equation 27).

$$
\begin{gathered}
X_{G}=X_{\mathrm{SiO}_{2}}+X_{\mathrm{P}_{2} \mathrm{O}_{5}} \\
X_{M}=X_{\mathrm{CaO}}+X_{\mathrm{MgO}}+3 X_{\mathrm{CaF}_{2}}+X_{\mathrm{FeO}}+X_{\mathrm{MnO}}+X_{\mathrm{TiO}_{2}} \\
X_{A}=X_{\mathrm{Al}_{2} \mathrm{O}_{3}}+X_{\mathrm{Fe}_{2} \mathrm{O}_{3}}+X_{\mathrm{B}_{2} \mathrm{O}_{3}}
\end{gathered}
$$

Normalized values $x_{G}^{*}, x_{M}^{*}, x_{A}^{*}$ are obtained by dividing the mole fractions, $x_{G}, x_{M}, x_{A}$ by the equation 28 ;

$$
1+X_{\mathrm{CaF}_{2}}+0.5 X_{\mathrm{FeO}}+X_{\mathrm{TiO}_{2}}+X_{K_{2} \mathrm{O}}
$$


The viscosity of slag (in poise) can then be determined by using the equation below;

$$
\mu_{\mathrm{s}}=\mathrm{AT} \exp \left(1000 \frac{\mathrm{B}}{\mathrm{T}}\right)
$$

Parameters $\mathrm{A}$ and $\mathrm{B}$ can be expressed as detailed below $\left(\alpha=x_{M}^{*} /\left(x_{M}^{*}+x_{A}^{*}\right)\right)$. The parameters for $\mathrm{B}$ are available on Table 2 .

$$
\begin{gathered}
B=B_{0}+B_{1} x_{G}^{*}+B_{2}\left(x_{G}^{*}\right)^{2}+B_{3}\left(x_{G}^{*}\right)^{3} \\
-\ln \mathbf{A}=\mathbf{0 . 2 6 9 3 . ~} \mathbf{B}+\mathbf{1 1 . 6 7 2}
\end{gathered}
$$

Table 2. B parameters for calculating the viscosity of slag [11]

\begin{tabular}{|c|}
\hline$B_{i}=\alpha_{i}+b_{i} \alpha+c_{i} \alpha^{2}$ \\
\hline$B_{0}=13.8+39.9355 \alpha-44.049 \alpha^{2}$ \\
\hline$B_{1}=30.481-117.1505 \alpha+139.9978 \alpha^{2}$ \\
\hline$B_{2}=-40.9429+234.0486 \alpha-300.04 \alpha^{2}$ \\
\hline$B_{3}=60.7619-153.9276 \alpha+211.1616 \alpha^{2}$ \\
\hline
\end{tabular}

As the viscosity of the slag is strongly influenced by the solid fraction $(\varepsilon)$ in the slag, the equation proposed (Equation 32) by Einstein-Roscoe is considered by Oeters [8].

$$
\mu_{\text {slag }}=\mu_{\mathrm{s}}(1-\varepsilon)^{-2,5}
$$

\subsection{Mass Transfer Coefficients}

Mass transfer coefficient can be estimated by semi-empirical relationship based on Sherwood, Reynolds and Schmidt numbers. Schmidt number for $\mathrm{CaO}$ and $\mathrm{MgO}$ can be found as a function of physical properties of slag and diffusivities of lime and dololime. Dogan [2] suggested that there are two different flow regimes in the slag due to the stirring conditions. The regime near the lance has a higher stirring intensity due to the $\mathrm{CO}$ gas generation. The regime far away from the lance and close to the refractory lining is expected to be more stagnant regime. Therefore, dissolution of solid particles in this stagnant regime takes place at a slower rate compared to that in the turbulent regime. As a practical solution to the problem, an empirical correlation for Reynolds Number (Re') was applied.

$$
\begin{gathered}
R e^{\prime}=10\left(\frac{u_{p} d_{p} \rho_{s}}{\mu_{s}}\right) \\
S c=\frac{\mu_{s}}{\rho_{s} \cdot D} \\
S h=1+0.724\left(R e^{\prime}\right)^{0,48} S c^{1 / 3} \\
k=\frac{S h . D}{d_{p}}
\end{gathered}
$$

It is assumed the diffusivity of $1.6 \times 10-5 \mathrm{~cm}^{2} / \mathrm{s}$ for $\mathrm{MgO} 1.400^{\circ} \mathrm{C}$, for $\mathrm{CaO}$ diffusivities, the table below (Table 3 ) is assumed. 
Table 3. Diffusivities of lime available at Matsushima research [1]

\begin{tabular}{|c|c|c|}
\hline $\boldsymbol{T}\left({ }^{\circ} \mathbf{C}\right)$ & $\boldsymbol{D}\left(\mathbf{c m}^{2} / \mathbf{s}\right)$ & $\boldsymbol{\mu}_{\text {slag }}$ (Poise) \\
\hline 1500 & $5.5 \times 10^{-6}$ & 9,2 \\
\hline 1400 & $2.7 \times 10^{-5}$ & 1,2 \\
\hline
\end{tabular}

In order to calculate the diffusivities of $\mathrm{CaO}$ and $\mathrm{MgO}$ for various temperatures, the equation of Stokes-Einstein and Eyring, $D \therefore T_{S} / \mu_{S}$, is considered by Dogan [2].

\section{RESULTS AND DISCUSSION}

Some experimental heats were conducted in order to validate and check the model at ThyssenKrupp CSA (TKCSA), Santa Cruz, Brazil. There are two state of art BOF installed, a nominal capacity of $350 t$ of charge and Thyssen Blowing Metallurgy (TBM) technology available.

An example for one typical chemical composition (Metal and Slag) is available in the table below (Table 4), and also the slag and metal behavior (Figure 1 and 2) for one simulated heat as result of the proposed slag model.

Table 4. Heat 740897 - Hot Metal and EOB steel analysis.

\begin{tabular}{|c|c|c|c|c|c|c|}
\hline Sample & $\mathbf{C}(\%)$ & Mn (\%) & $\mathbf{P ~ ( \% )}$ & $\mathbf{S}(\mathbf{p p m})$ & $\mathbf{S i}(\%)$ & $\begin{array}{c}\text { Oxygen } \\
(\mathbf{p p m})\end{array}$ \\
\hline Hot Metal & 4,97 & 0,44 & 0,096 & 12 & 0,52 & - \\
\hline Steel EOB & 0,03 & 0,14 & 0,013 & 23 & 0,00 & $516 \mathrm{ppm}$ \\
\hline Sample (\%) & $\mathbf{C a O}$ & $\mathbf{S i O 2}$ & $\mathbf{F e}(\mathbf{T})$ & $\mathbf{M g O}$ & MnO & $\mathbf{P 2 O 5}$ \\
\hline Slag EOB (Sample) & 48,8 & 12,5 & 16,1 & 7,6 & 3,3 & 2,1 \\
\hline Slag EOB (Model) & 51,2 & 12,4 & 15,9 & 6,8 & 4,6 & 1,9 \\
\hline
\end{tabular}

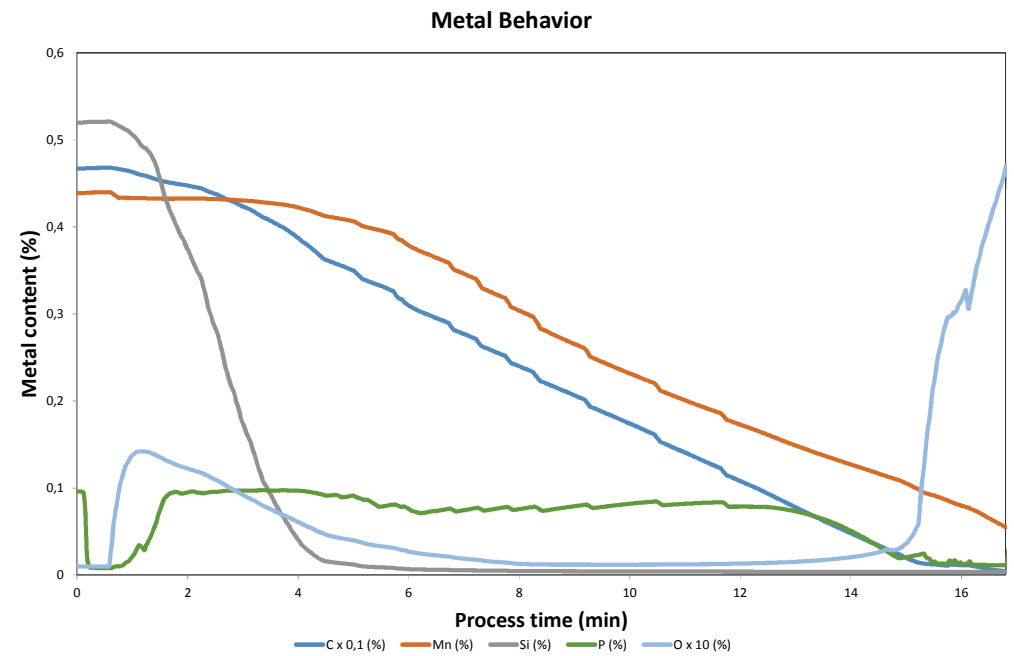

Figure 1. Typical metal behavior during BOF blow - Heat 740897. 


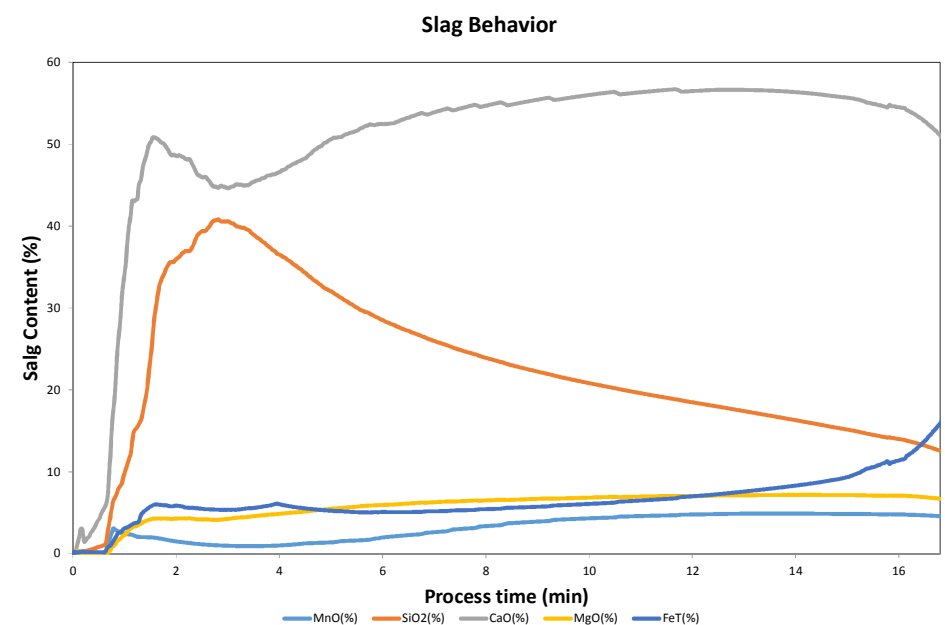

Figure 2. Typical Slag Behavior during BOF blow. Heat 740897.

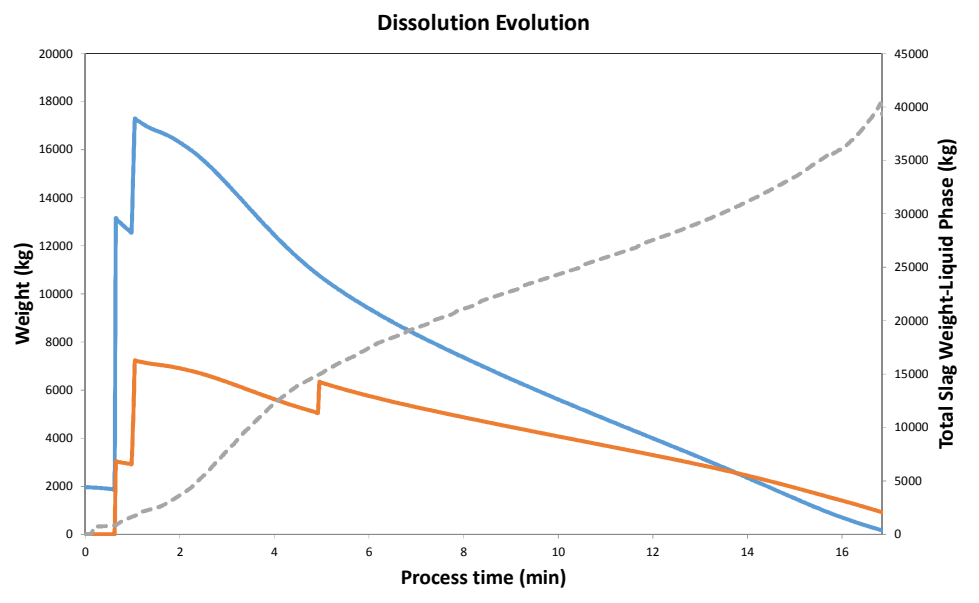

Figure 3. BOF slag mass behavior between liquid and solid phase during blow. Heat 740897 .
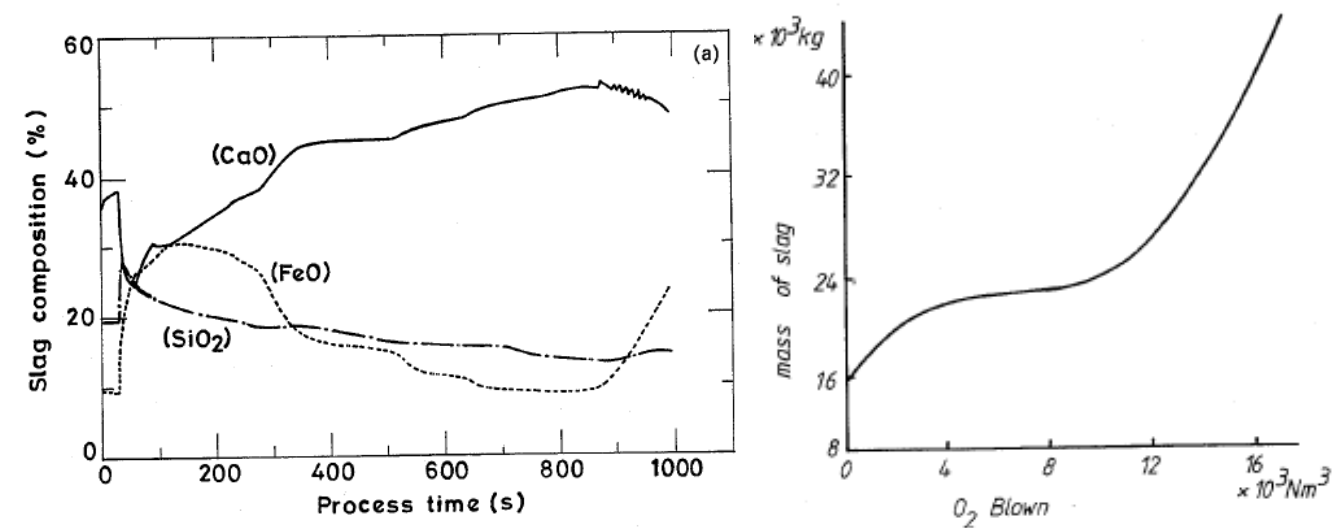

Figure 4. (Left) Evolution of slag composition by dynamic slag-droplet model proposed by Brahma Deo [9]. (Right) Increasing mass of slag with oxygen blown in $300 \mathrm{t}$ converter at Hoogovens ljmuiden.

According to Figure 2 and 3 for the first step of the blow, an acid slag is formed from oxidized $\mathrm{Si}$ and $\mathrm{Fe}$, the lime is only very partially dissolved and the temperature is low, so that part of the phosphorus is oxidized. Then, in the second step, lime is progressively dissolved with enrichment of liquid slag in $\mathrm{CaO}$ and decrease in $\mathrm{FeO}$ content due to dilution and $\mathrm{FeO}$ reduction during full decarburization. It means a heterogeneous slag and non-reactive with respect to phosphorus. At the end, the slag is reactive and suitable for final dephosphorization. as shown in Figure 1 and 2. 


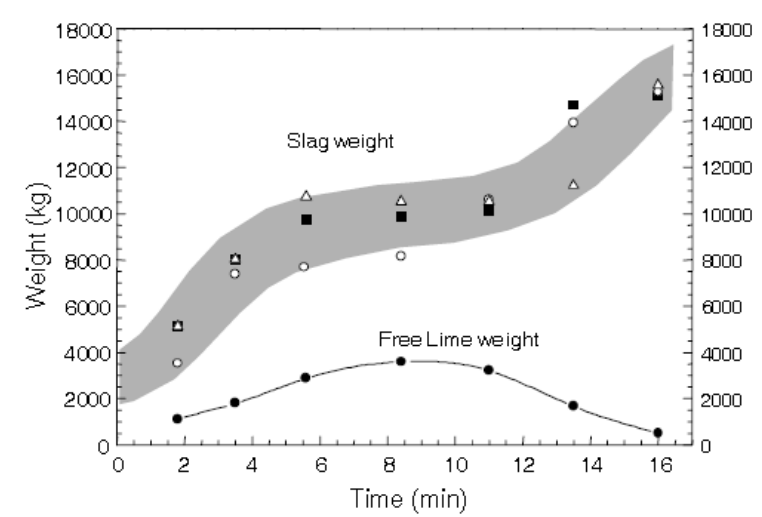

Figure 5. Slag weight and free lime content along the process at Siderar steel plant in a recent study of Cicutti [10] about an analysis of slag foaming.

Establishing a comparison between the proposed model (Figures 3 and 2) and the study developed by Cicutti [10], on Figure 5, and also the models proposed by Brahma Deo [10], on Figure 4, the results of proposed model are in accordance with the literature. The different curve for free lime, is regarding to different additions steps between both plants, at TKCSA $90 \%$ of lime addition is made just after the ignition, at Siderar there is an addition of $1000 \mathrm{~kg}$ of lime before start the process, and the $6600 \mathrm{~kg}$ in first half of the process. All heats simulated below (Figure 6) were carried out in a BOF without slag splashing procedure just before the simulated heat (remaining slag were not considered). Also, the dissolution of BOF lining to slag was not considered.

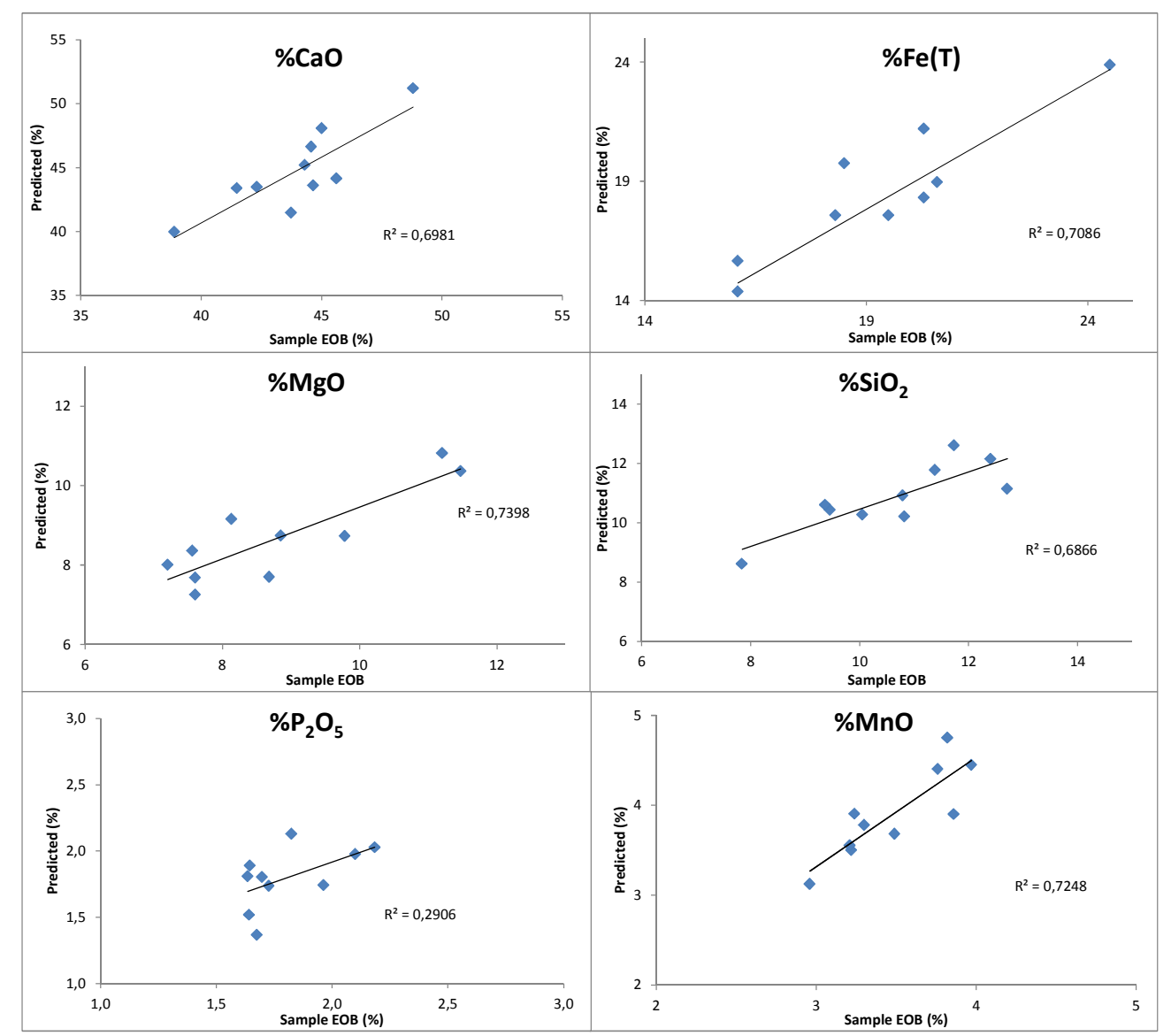

Figure 6. Comparison between slag samples at the end of BOF blow (EOB) X Predicted by current work. 


\section{CONCLUSION}

A suitable model were developed and proposed, a comparison between slag sample and predicted values by the proposed model at BOF end of blow were done (Figure 6), as well literature validation with previously works, as already mentioned before. All of the mentioned comparisons displayed a good consistency. Nevertheless, there is still an opportunity to improve the phosphorous modeling (Figure 6), some other challenging points to be considered are the suction of flux by a primary dedusting system, which is estimated to be around $5-10 \%$ in TKCSA regular process. A good technical approach for this issue can be a combination of process data and the modeling of terminal velocity in the presence of buoyancy force. One other important point is the dissolution of BOF lining and slag-splashing "cover" in the subsequent heat. A better comprehension for BOF lining dissolution over the process is a key point not only to improve the slag modeling, but also to improve the BOF lining life time, by reducing the refractory wear.

\section{REFERENCES}

1 Matsushima, Masaaki, et al. 1977. A Fundamental Study on the Dissolution Rate of Solid Lime into Liquid Slag. Trans. Iron Steel Inst. Jpn. 1977, p. 442.

2 Dogan, Neslihan, Brooks, Geoffrey and Rhamdhani, Muhamad. 2009. Kinetics of Flux Dissolution in Oxygen Steelmaking. ISIJ International. 2009, Vol. 49, 10, pp. 1474-1492.

3 Schürmann, Eberhard, Schmöle, Peter e Kolm, Ingo. 1985. Verlauf der Kalksättigung im System $\mathrm{FeO}-\mathrm{Fe}_{2} \mathrm{O}_{3}-\mathrm{CaO}-\mathrm{SiO}_{2}-\mathrm{P}_{2} \mathrm{O}_{5}-\mathrm{MgO}-\mathrm{MnO}$ beim Gleichgewicht mit einer Eisenschmelze. Steel Research. 56, 1985.

4 Umakoshi, M., Mori, K. e Kawai, Y. 1984. Trans. Iron Steel Inst. Jpn. 1984, Vol. 24, p. 532.

5 Schurmann, E.; Kolm, I. Mathematical description of magnesia saturation in complex steelmaking slags in equilibrium with liquid iron. Steel Res. 1986, 57, 7-12.

6 Keene, B. J. e Mills, K.C. 1995. Densities of Molten Slags. [ed.] Verein Deutscher Eisenhüttenleute (VDEh). Slag Atlas. Düsseldorf : Verlag Stahleisen GmbH, 1995.

7 Mills, K. C. 1995. Viscosities of Molten Slags. [ed.] Verein Deutscher Eisenhüttenleute (VDEh). Slag Atlas. 2a. Düsseldorf : Verlag Stahleisen GmbH, 1995, pp. 349-397.

8 Oeters, Franz. 1989. Metallurgie der Stahlherstellung. Berlin : Stahl Einsen, 1989

9 Deo, Prof. Dr. Brahma, Mazumdar, Dipak e Chakraborti, Nirupam. 1998. Modeling and simulation on iron and steelmaking. s.I. : REM, 1998, pp. 210-216.

10 Cicutti C., Valdez M.,Pérez T., R. Donayo, J. Petroni. 2009. Analysis of slag foaming during the operation of an industrial converter. Latin America Applied Research. 2009, Vol. 32.

11 Slag Atlas. 1995. M. Allibert, et al. [ed.] Verein Deutscher Eisenhüttenleute (VDEh). 2a. Düsseldorf : Verlag Stahleisen GmbH, 1995. 